\title{
Introduction
}

\section{Thomas Berry and the Arc of History}

\begin{abstract}
The account of how I became increasingly aware of the cosmological and biological dimensions of existence is the story of my life. My quest for understanding this larger context of things conditioned all the decisions I made about my life. I saw life within its larger context, eventually within the context of the universe itself. I was immersed in the mystery of things, in the mysterious powers expressed in natural phenomena. The various living beings I experienced as integral with my own existence.
\end{abstract}

Thomas Berry, Goldenrod: Reflections on the Twentieth Century

I n the autumn of 1994, Thomas Berry turned eighty. Still in good health, he was planning to move from New York City back to his birthplace in Greensboro, North Carolina. As Mary Evelyn Tucker and John Grim were helping him pack up and distribute his library, they would pause at the end of the day and share a meal and a glass of wine together. While the sun set over the ancient rock cliffs of the Palisades across the Hudson River, they sensed the transition of a life lived in the depths of time-biological and geological. As they began to reflect together on the best approach to his biography, Thomas would invariably say: "Tell my story in the context of the times."

That refrain was a guiding mantra in preparing his biography within the arc of history. It was a formidable task, as Thomas Berry's long life (1914-2009) spanned the major events of the twentieth century, from the First World War at the time of his birth to significant climatic and ecological disruption around the planet in his later years. Moreover, his intellectual breadth and 
spiritual depth defy adequate description. He was widely read in world history and religions and spent his early years within the contemplative rhythms of monastic life.

He lived immersed in the narratives of time that were continually expandingfrom human history, to Earth history, to universe history. He sought a way to be grounded in the great vessel of life, the cosmos itself. He evoked this grounding with the power of story. He could tell stories that would capture a room and would leave the audience clamoring for more. His storytelling was based on a profound attention to the past, a passion for history, and a comprehensive compassion for the present with its multifaceted challenges. These sensibilities rested in the "mysterious powers expressed in natural phenomena": the bird songs and migrations, the living forests and ancient mountains, and the roaring force of oceans and rivers. All these powers were connected to star birth, out of which the elements of life emerged.

He spoke from a place of erudition mingled with an engaging poetic rhetoric. His presence was one of laughter and luminosity; his words penetrated the soul and enlivened the mind. Indeed, his lucid language broke out of scholarly constraints to bring rays of hope into the eyes of young and old alike. There are few people who have grappled for so long and so steadfastly with bringing a healing vision for the Earth community. ${ }^{2}$

What motivated him in this task? Thomas lived through some of the most remarkable and rapid changes in recorded history-from electrical energy to solar energy, from community phone lines to personal cell phones and computers, from horse-and-buggy travel to placing a man on the moon. He sought throughout his life to make sense of these changes. His constant question was: "What is progress, and what is its real cost?" He intuited at a very early age that something was being lost-not just in the agrarian life of the South, where he was raised, but also in the depths of the integral functioning of the planet itself with the race to industrialize and modernize. Toxic chemicals seeped into soils and streams while greenhouse gases in the atmosphere caused massive climate change. He would spend his life trying to respond to the loss of ecosystem health and biodiversity with an encompassing and enlivening vision. He began where the environmentalist John Muir ended. Indeed, Thomas came into the world in 1914, the same year Muir died. They shared a love of wilderness and 
consternation at its destruction due to unregulated logging, overgrazing by pastoralists, and relentless extractive industries.

Thomas was born into a recently expanded Union and a newly initiated world war. Two years earlier, in 1912, Arizona and New Mexico joined the Union, thus completing the forty-eight states of the United States mainland. The westward expansion of the prior hundred years was over, and joyful celebrations were held. However, as Thomas understood later, this "Union" came at the expense of Native Americans, who were subsumed into a new republic that had long suppressed their traditional cultures and lifeways. Similarly, while slavery was legally outlawed, full participation of African Americans in educational or economic opportunities was still unrealized. An economy and politics of inclusion were struggling to emerge across the country and throughout his lifetime. He lamented that this aspiration toward broader inclusion was still not realized at the time of his death.

Ethnic, political, and economic tensions were not restricted to the United States but were a worldwide phenomenon of the twentieth century. In July 1914, just four months before Thomas was born, World War I broke out in Europe with the unpredictable assassination of Archduke Ferdinand by a Serbian nationalist. By the end of the war, four great empires had collapsed: German, Russian, Austro-Hungarian, and Ottoman. The Russian Revolution had taken place in 1917. A new world order was coming into being with the armistice in 1919 and the formation of the League of Nations in 1920. Its goal was to promote peace and disarmament through negotiations and arbitration. But President Woodrow Wilson could not persuade the United States to join due to the strength of the isolationist lobby. Moreover, because the League had no military power, various international conflicts could not be resolved. Thus, the League faltered, and the peace did not last. It would take the Depression of the 1930 and another world war for the United Nations to be founded in 1945 and the European Union to emerge in the postwar period. These international and regional institutions also faced upheavals caused by ethnic differences and political conflicts. A continuing challenge was the growing ideology of nationalism, which led to tensions on the international scene as well as within nation-states. Indeed, European historian Carlton J. H. Hayes, who was an important influence on Berry, titled his last book, Nationalism: A Religion. ${ }^{3}$ 
All of this was part of the world in which Thomas Berry was born and grew up, and to which he eventually responded. He was searching for a way beyond such divisions, toward a story that could draw the human community together into a whole that was larger than the nation-state. He created the term Earth community to indicate our shared sense of belonging to something greater-humans and nature in continuity. Against all odds, and in the midst of endless conflicts, he persisted in his quest to understand how such an enlivening narrative could emerge from the upheavals of modern history and rapid technological change. He experienced these upheavals in China with the Maoist revolution and in Germany with the Cold War. He had to leave China in 1948 as Mao's troops moved into Peking. He lived for three years in the 1950 s with American troops in a Germany divided between a communist East and democratic West. And in the 1960 he witnessed demonstrations on American campuses against the Vietnam War and for civil rights. He, like President Dwight Eisenhower, grew wary of the power of the "military-industrial complex."

The post-World War II economic boom brought growth and prosperity to various parts of the world, but at immense cost to the environment and to social equity. As the human community exploded from 2 billion, when he was born, to 7 billion three years after he died, these environmental and social problems became exacerbated. Thus, it would require two United Nations conferences (in Stockholm in 1972 and Rio in 1992) to call the nations of the world to address the escalating tensions of economic development and environmental protection.

In the decade between these conferences, the World Charter for Nature was written and endorsed in 1982 by all members of the United Nations except the United States. Thomas held this Charter in high esteem for its eloquent recognition of nature as the basis of all life. The leaders of the Rio Earth Summit expanded on this idea by calling for an Earth Charter in 1992. This initiated many years of careful drafting by an international committee led by Steven Rockefeller, a professor of religion at Middlebury College. The Earth Charter was completed at the end of the twentieth century, a decade before Thomas died. The document is a comprehensive vision of the interconnections of cosmology, ecology, justice, and peace. It has been called a Declaration of Interdependence for a shared planetary future. The preamble includes Thomas's view that "[h]umanity is part of a vast evolving universe. Earth, our home, is alive with a unique community of life." 
Thomas spent his life navigating between the forces of nationalism and internationalism and between the tensions of ecological conservation and economic growth. All the while, he was working on a new inclusive framework for humans and nature, eventually articulating a comprehensive ecological sense of the Earth community. From this perspective, humans are seen not simply as political or economic entities, but as biocultural beings amidst the vast diversity of life systems and species. This viewpoint, he felt, changes everything. Thus, Thomas Berry expanded his life quest to articulate an engaging evolutionary narrative that would respond to the overwhelming ecological and social crises facing the human community.

Thomas's journey has shaped the structure of this biography: the first eight chapters focus on the chronological unfolding of his life, and the final four chapters elaborate his thought. He began his life in Greensboro, North Carolina, entered the monastery, did graduate studies in history, went to China, then to Germany, and returned to the United States to begin teaching. He built a History of Religions program at Fordham and a place for broader reflection at the Riverdale Center for Religious Research along the Hudson River. Even in his retirement back to Greensboro he inspired programs in education, law, religion, and agriculture.

From his beginnings as a cultural and intellectual historian, Berry became a historian of the Earth. While some described him as a theologian, as he taught in a theology department at Fordham, Berry preferred to describe himself as a "geologian." The movement from human history to Earth history was a necessary progression for Berry. He witnessed in his own lifetime the emergence of a multicultural planetary civilization as cultures came in contact around the globe, often for the first time. But he wanted to place this emergence in the larger arc of Earth history and the evolution of the universe. He saw humans as arising out of the journey of the universe, unfolding over billions of years of dynamic evolution. He recognized the power of an evolutionary story to engage humans in the great questions: where have we come from, how do we belong, why are we here?

This is what led to his signature essay "The New Story" in 1978. A new universe story, he felt, could help humans become mutually enhancing participants in the life community. ${ }^{6}$ He worked for over a decade to write The Universe Story with Brian Thomas Swimme. This was the grounding for the transformations that he saw were needed for a new period in human history, one he called the Ecozoic era. 


\section{xviii Introduction}

Inspired by creative thinkers in ecological forms of economics, politics, education, law, and religion, Berry believed that such a period was not only possible but already emerging. This is the promise of Berry's perspective. It is one that adds fresh energy to what he called the "Great Work," namely, what each person and community can contribute to a flourishing future. As he would say, "This work is for the future generations of all species." It is in this context of a great story inspiring great work that he saw the arc of history unfolding. 
THOMAS BERRY

Wr 
